Tropical Journal of Pharmaceutical Research December 2013; 12 (6): 989-995

ISSN: $1596-5996$ (print); 1596-9827 (electronic) (C) Pharmacotherapy Group, Faculty of Pharmacy, University of Benin, Benin City, 300001 Nigeria. All rights reserved.

\title{
In vitro Activity and Safety Assessment of New Synthesized Thiazolo Pyrimidine Derivatives Augmented with Albendazole against Echinococcus Multilocularis Metacestodes in Balb/C Mice
}

\author{
Saleh A Bahashwan ${ }^{1^{*}}$, Ahmed E Alharbi ${ }^{2}$, Mohamed A Ramadan ${ }^{2}$, Ahmed A \\ Fayed $^{3,4}$ and Ahmed A Bahashwan ${ }^{5}$ \\ ${ }^{1}$ Pharmacology and Toxicology Department, College of Pharmacy, Microbiology/lmmunology Department, College of Medicine, \\ Taibah University, Medina Munawarah, ${ }^{3}$ Respiratory Therapy Department/Applied Organic and Biochemistry Division, College \\ of Medical Rehabilitation Sciences, Taibah University, ${ }^{4}$ National Research Centre, Cairo, Egypt, ${ }^{5}$ Laboratory Department, \\ Maternity and Children's Hospital, Ministry of Health, Medina Munawarah, Saudi Arabia
}

*For correspondence: Email: bhswn@yahoo.com; Tel: +966-590045053

\begin{abstract}
Purpose: To synthesis a series of novel thiazolo pyrimidine derivatives and evaluate them in vitro for their safety and anthelmintic activity against $E$. multilocularis metacestodes using BALB/C mice.

Methods: A new series of substituted amino thiazole, hydrazinothiazole and thiazolo pyrimidine derivatives (2-6) were synthesized by reaction of compound 1 with potassium isothiocyanate to give the corresponding compound 2, which was used as starting material. The physicochemical characterization of these derivatives was carried out by nuclear magnetic resonance spectroscopy $\left({ }^{1}\right.$ HNMR) and mass spectroscopy (MS). The purity of the compounds was determined by elemental analysis. Safety and anthelminthic activity of the compounds against E. multilocularis metacestodes was evaluated in vitro by i) viability assessment and relative abundance of 14-3-3 mRNA determination in E. multilocularis metacestodes-suspensions treated with 2, 5 and $10 \mu \mathrm{M}$ concentrations of each compound separately. ii) bioassay at 15 weeks post-inoculation of mice by $E$. multilocularis suspensions-treated with $30 \mu \mathrm{M}$ albendazole (ABZ), $10 \mu \mathrm{M}$ thiazolopyrimidine derivative 5 (TPYDa) and a combination of both. Liver functions of all mice were tested before mice sacrifice.

Results: TPYDa emerged as the active anthelmintic compound of the series against E. multilocularis metacestodes viability (activity, $60 \%$ ) compared with ABZ (activity, $63 \%$ ). When TPYDa was combined with $A B Z$, the activity reached $86 \%$. No mortality was found and liver function was normal in all mice during the studies.

Conclusion: The compound, TPYDa, can serve as a lead molecule for further development to a clinically useful novel class of anthelmintic agents.
\end{abstract}

Keywords: Thiazolopyrimidine, Synthesis, Echinococcosis, Mice, Chemotherapy

Tropical Journal of Pharmaceutical Research is indexed by Science Citation Index (SciSearch), Scopus, International Pharmaceutical Abstract, Chemical Abstracts, Embase, Index Copernicus, EBSCO, African Index Medicus, JournalSeek, Journal Citation Reports/Science Edition, Directory of Open Access Journals (DOAJ), African Journal Online, Bioline International, Open-J-Gate and Pharmacy Abstracts

\section{INTRODUCTION}

Hepatic echinococcosis is a life-threatening disease, mainly differentiated into alveolar and cystic forms, associated with Echinococcus multilocularis (E. multilocularis) and Echinococcus granulosus (E. granulosus) infection respectively. Cystic Echinococcosis 
(CE) has a worldwide distribution, while hepatic Alveolar Echinococcosis (AE) is endemic in the Northern hemisphere, including North America, several Asian and European countries [1]. In human patients, $E$. multilocularis forms multilocular metacestodes that exhibit growth and/or proliferation of metacestodes over a long period of time leads to the development of space-occupying lesions, causes organ dysfunction, and can occasionally lead to death [2].

Benzimidazole carbamate derivatives such as albendazole and mebendazole are currently the drugs of choice. For treatment of $A E$, benzimidazole treatment has been shown to act parasitostatic rather than parasitocidal for many cases, and the recurrence rates after interruption of therapy in not radically operated cases are higher [3]. Thus, new options for chemotherapy are needed, anticipating a parasitocidal activity if possible. 14-3-3 proteins are found in all eukaryotic cells and participate in protein signaling pathways. They function as phosphoserine/phosphothreonine-binding modules and have an effect on phosphorylationdependent events, such as DNA-damage checkpoints and prevention of apoptosis [4].

Some 14-3-3 proteins have been shown to be aberrantly expressed in tumor cells, acting either pro- or anti-tumorogenic and there are a number of similarities between cancer cells and some parasites, particularly echinococcus [5]. Similarities include features such as the essentiality unlimited proliferative capacity of protoscoleces/brood capsules, the potential to modulate the immune response, the secretion of proteolytic enzymes to reach their target sites or organs, and the formation of metastases [6]. E. multilocularis metacestodes behave like malignant tumors, over-expression in metacestodes of 14-3-3 proteins. Indeed, when echinoccocus 14-3-3 sequences are aligned in metacestodes group with the tumor-growth related zeta-isoforms of neoplastic mammalian cells [7].

New synthesized thiazolopyrimidine (TPYD) derivatives; hetero-cyclic compounds were found to possess a variety of pronounced activities such as anti-parkinsonism, hypoglycemic, antimicrobial activities [8] antiinflammatory, analgesic [9-10], anti-avian influenza virus (H5N1) [11], against herpes simplex virus type-1 (HSV-1) and hepatitis-A virus (HAV) [12], serotonin $5-\mathrm{HT}_{6}$ receptor antagonist [13]. Heterocyclic compounds were reported as inhibitors of glycogen synthase kinase-3(GSK-3) and potent anti-tumor agents [14-15]. As an extension of our ongoing studies, the objective of the present work is to synthesis a series of TPYD derivatives and evaluates them both in vitro and in vivo for their anthelmintic activities against experimental $E$. multilocularis metacestodes in mice.

\section{EXPERIMENTAL}

\section{Synthesis \\ 2-Amino naphthalino [1,2-d]thiazolo, compound 2}

A mixture of compound $1(0.01 \mathrm{~mol})$ and $\mathrm{KSCN}$ $(0.01 \mathrm{~mol})$ in acetic acid $(50 \mathrm{ml})$ was placed in freezing mixture and stirred mechanically with addition of $\mathrm{Br}_{2}(0.2 \mathrm{~mol})$ for $2 \mathrm{~h}$ at $0-10{ }^{\circ} \mathrm{C}$. The reaction mixture was poured onto ice-water, the formed solid product was collected by filtration, washed with water, dried and crystallized from ethanol to give compound 2 as green powder.

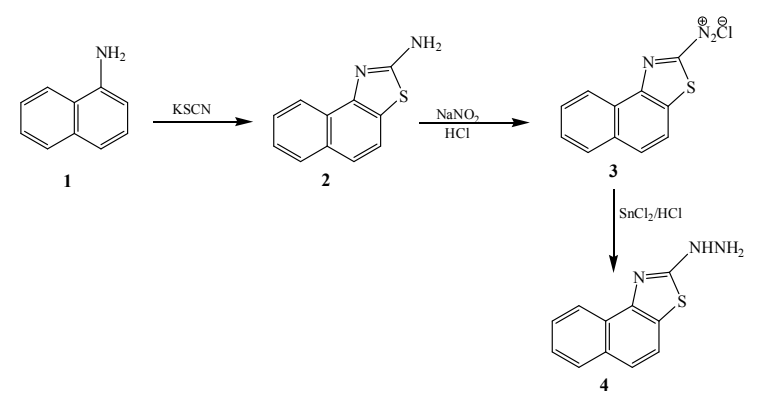

Scheme 1: Synthesis of compounds $2-4$

\section{2-Diazo naphthalino [1,2-d]thiazolo, compound 3}

A stirred solution of compound $2(0.01 \mathrm{~mol})$ in 35 $\% \mathrm{HCL}(10 \mathrm{ml})$ was diazotized at $0-5{ }^{0} \mathrm{C}$ by a solution of $30 \%$ aq. $\mathrm{NaNO}_{2}$. Then, the solution poured onto ice water and the solid product was crystallized from ethanol to give compound 3 as yellow powder.

\section{2-Hydrazino naphthalino [1,2-d]thiazolo, compound 4}

A mixture of diazonium salt $3(0.01 \mathrm{~mol})$ and stannous chloride $(0.01 \mathrm{~mol})$ in concentrated hydrochloric acid $(40 \mathrm{ml})$ was stirred over night at room temperature. After cooling $\left(-10{ }^{\circ} \mathrm{C}\right)$, the obtained solid was filtered off, washed with water, dried, and crystallized from the ethanol to give compound 4 as brown powder.

A solution of compound $2(0.01 \mathrm{~mol})$ in DMF (20 $\mathrm{ml}$ ) was added benzylidine ethyl cyano acetate (0.01 mol) and piperidine (2 drops) refluxed $3 \mathrm{~h}$, the solvent was evaporated under reduced pressure and the remaining product was triturated with water and acidified with conc. HCL. After filtration the separated solid was 
collected and crystallized from ethanol to give compound 5 as yellow powder.<smiles>CCOC(=O)C1=C(N)N=C2Sc3ccc4ccccc4c3N2C1c1ccc(Cl)cc1</smiles>

5

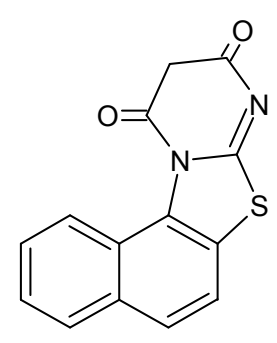

6
Scheme 2: Synthesis of compounds 5 and 6

\section{3,5-Dioxo-4H-pyrimidino [3,2-b]naphthalino [1,2-d] thiazolo, compound 6}

A mixture of compound $2(0.1 \mathrm{~mol})$ and diethyl malonate $(0.1 \mathrm{~mol})$ in glacial acetic acid (30 $\mathrm{ml}$ ), in the presence of few drops tri-ethyl-amine, was refluxed for $3 \mathrm{~h}$. The reaction mixture was poured into water; the separated solid was collected and crystallized from ethanol to give compound 6 as green powder.

\section{Elemental and spectral analysis}

Melting points were determined on open glass capillaries using Electro thermal IA 9000 digital melting point apparatus (Electro thermal, Essex, UK.) and are uncorrected. Elemental analyses were performed with all final compounds on Elementar, Vario EL, Micro Analytical Unit, National Research Centre, Cairo, Egypt and were found within $\sim 0.4 \%$ of the theoretical values. Analytical data were obtained from the Micro analytical Unit, Cairo University, Egypt. The IR spectra $(\mathrm{KBr})$ were recorded on a FT IR8201 PC spectrophotometer. The ${ }^{1} \mathrm{H}-\mathrm{NMR}$ spectra was measured with Jeol FTGNM-EX 270, $270 \mathrm{MHz}$ instrument in DMSO- $\mathrm{d}_{6}$ and the chemical shifts were recorded in $(\delta, \mathrm{ppm})$ relative to TMS. The mass spectra were run at $70 \mathrm{eV}$ with a Finnigan SSQ 7000 spectrometer using $\mathrm{El}$ and the values of $\mathrm{m} / \mathrm{z}$ are indicated in Dalton. TLC (Silica gel, aluminum sheets $60 \mathrm{~F}_{254}$, Merck, Darmstadt, Germany) followed the reactions.

\section{Culture of E. multilocularis metacestodes}

Six weeks old female BALB/c mice, 16-18 g each were used. Approval of the institutional animal ethical committee for animal studies was obtained from the Office of Environmental Health and Radiation Safety, ACUC protocol \# 1096-5. Animals were housed in a temperature- controlled, light cycle room in animal facilities according to American and European federal animal protection guidelines, with food and water ad libitum. In vitro cultivation of $E$. multilocularis metacestodes was carried out as previously described [16]. Briefly, mice were infected intraperitoneally with E. multilocularis clone KF5. After 2-3 months, the animals were euthanized and the parasite tissue was recovered from the peritoneal cavity under a septic conditions. The tissue pieces were cut into small tissue blocks $\left(0.5-1 \mathrm{~cm}^{3}\right)$, and several pieces of tissue were placed in $75 \mathrm{ml}$ of culture medium (RPMI) 1640 containing $25 \mathrm{mM}$ HEPES, $4 \mathrm{mM}$ L-glutamine, $100 \mathrm{U}$ of Penicillin $/ \mathrm{ml}$ and $100 \mu \mathrm{g}$ of Streptomycin $/ \mathrm{ml}$ ) supplemented with $10 \%$ fetal calf serum (FCS) and phenol red. Tissue blocks were kept in tightly closed culture flasks $(200 \mathrm{ml})$ placed in an upright position in an incubator at $37{ }^{\circ} \mathrm{C}$ with $5 \%$ $\mathrm{CO}_{2}$, with medium change every week. These metacestodes were used for in the vitro compounds assays as described below. The synthetic compounds were dissolved in DMSO (stock solution of $10 \mathrm{mM}$ ). Albendazole was purchased from Sigma Aldrich (St. Louis, MO, USA). All tissue culture media and biochemical reagents were purchased from Invitrogen (Basel, Switzerland).

In vitro metacestodes treatment, growth assays, histological studies and 14-3-3 protein mRNA PCR quantitation

Free floating metacestodes with diameters between 1 and $5 \mathrm{~mm}$ were harvested, washed 3 times in serum free medium and divided into separate cultures in $15 \mathrm{ml}$ of RPMI medium without FCS and phenol red. The tested compounds were added to the cultures separately, yielding final concentration of 2, 5 and $10 \mu \mathrm{M}$. Control cultures were performed with corresponding amounts of DMSO alone. Treatment was carried out at $37{ }^{\circ} \mathrm{C} / \mathrm{CO}_{2}$ for 7 days. At day 7 , metacestodes were processed for in vitro compounds assays using light microscopy, scanning and transmission electron microscopy (SEM/TEM) as described by [17]. Also, the relative quantification of 14-3-3 mRNA expression was performed. Briefly, the total RNA was extracted employing the RNeasy mini kit (Qiagen). The total RNA was used to synthesize cDNA using Omnitranscriptase kit (Qiagen). Quantitative real-time PCR was performed using the Lightcycler ${ }^{\mathrm{TM}}$ instrument (Roch) with primers and conditioned established for quantitation of 14-3-3 and actin-transcripts as previously described [18]. 
Bioassay of $E$. multilocularis metacestodes viability in mice

In order to investigate in vitro compoundstreated metacestodes for viability or non-viability, mice (8 animals per group), were infected by intraperitoneal injection of $100 \mu \mathrm{l}$ metacestodes suspension. Before inoculation, the suspension had been prepared by isolation of parasite metacestodes tissue from mice as described above. The parasite tissue was pressed through a sterile metal sieve and the obtained suspension was distributed to five culture flasks containing $10 \mathrm{ml}$ culture medium with FCS and phenol red. Treatment of the culture was as follows: (i) $10 \mu \mathrm{M}$ TPYDa (ii) $30 \mu \mathrm{M} A B Z$ (iii) a combination of $10 \mu \mathrm{M}$ TYPYDa/30 $\mu \mathrm{M} \mathrm{ABZ}$ and (iv) DMSO alone as a control. Medium was changed with addition of fresh drugs on days 5 and 10 . On day 14, all suspensions were concentrated by short centrifugation and used for mice infection. At 15 weeks post-inoculation, mice were sacrificed, dissected, parasite tissue removed from the peritoneal cavity and the parasite weight was determined as previously described [19]. Before animal sacrificed, heparinized blood was collected by heart puncture and plasma levels for analine aminotransferase (ALT) and aspartate aminotransferase (AST) were measured using mice kits, according to routine clinical chemical methods (Department of Clinical Chemistry, Maternity and Children's Hospital, Medina Munawarah, KSA).

\section{Statistical analysis}

This was carried out using SPSS, version 8.0 software. Statistical significance was determined using one-way analysis of variance (ANOVA) and Student t-test. $P$ < 0.05 was set as the level of significance.

\section{RESULTS}

\section{Chemistry \\ 2-Amino naphthalino [1,2-d]thiazolo, compound 2}

Yield $68 \%$; mp $285{ }^{0} \mathrm{C}$; IR $\left(\mathrm{KBr}, \mathrm{cm}^{-1}\right): 3285$ $\left(\mathrm{NH}_{2}\right) ;{ }^{1} \mathrm{H}-\mathrm{NMR}$ (DMSO-d $): \delta: 6.14\left(\mathrm{~s}, 2 \mathrm{H}, \mathrm{NH}_{2}\right.$, exchangeable with $\left.\mathrm{D}_{2} \mathrm{O}\right), 7.12-7.38(\mathrm{~m}, 6 \mathrm{H}, \mathrm{ArH})$ $\mathrm{ppm}$; MS $\mathrm{m} / \mathrm{z}(\%) 200\left(\mathrm{M}^{+}, 23\right)$ corresponding to the molecular formula $\mathrm{C}_{11} \mathrm{H}_{8} \mathrm{~N}_{2} \mathrm{~S}$ and at 184 (100, base peak).

\section{2-Diazo naphthalino [1,2-d]thiazolo, compound 3}

Yield 67\%; mp $248{ }^{\circ} \mathrm{C}$; IR $\left(\mathrm{KBr}, \mathrm{cm}^{-1}\right)$ : $1615-$ 1430 $(\mathrm{C}=\mathrm{N}, \mathrm{C}=\mathrm{C}, \mathrm{Ar}) ;{ }^{1} \mathrm{H}-\mathrm{NMR}\left(\mathrm{DMSO}-\mathrm{d}_{6}\right) \delta: 6.92-$ 7.41(m,6H,Ar-H)ppm; MS m/z (\%): 212( $\left.\mathrm{M}^{+}, 38\right)$ corresponding to the molecular formula $\mathrm{C}_{11} \mathrm{H}_{6} \mathrm{~N}_{3} \mathrm{~S}$ and at 126 (100, base peak).

\section{2-Hydrazino naphthalino [1,2-d]thiazolo, compound 4}

Yield $79 \%$; mp $262{ }^{\circ} \mathrm{C}$; IR $\left(\mathrm{KBr}, \mathrm{cm}^{-1}\right)$ : 3340$3280\left(\mathrm{NH}, \mathrm{NH}_{2}\right) ;{ }^{1} \mathrm{H}-\mathrm{NMR}$ (DMSO-d $\left.{ }_{6}\right) \delta: 5.67$ $\left(\mathrm{s}, 1 \mathrm{H}, \mathrm{NH}\right.$, exchangeable with $\left.\mathrm{D}_{2} \mathrm{O}\right), 7.12-7.65$ $(\mathrm{m}, 6 \mathrm{H}, \mathrm{Ar}-\mathrm{H}), 10.31$ (b, $2 \mathrm{H}, \mathrm{NH}_{2}$, exchangeable with $\mathrm{D}_{2} \mathrm{O}$ ) $\mathrm{ppm}$; $\mathrm{MS} \mathrm{m} / \mathrm{z}(\%): M S \mathrm{~m} / \mathrm{z}(\%): 215$ $\left(\mathrm{M}^{+}, 21\right)$ corresponding to the molecular formula $\mathrm{C}_{11} \mathrm{H}_{9} \mathrm{~N}_{3} \mathrm{~S}$ and at 132 (100, base peak).

\section{3-Amino-4-ethoxy carbonyl-5-(4-chloro phenyl) pyrimidino[3,2-b]naphthalino [1,2-d] thiazolo, compound 5 (TPYDa)}

Yield 62\%; mp $225{ }^{\circ} \mathrm{C}$; IR $\left(\mathrm{KBr}, \mathrm{cm}^{-1}\right): 3270$ $\left(\mathrm{NH}_{2}\right), 1730\left(\mathrm{C}=\mathrm{O}\right.$ ester); ${ }^{1} \mathrm{H}-\mathrm{NMR}$ (DMSO-d $\left.\mathrm{d}_{6}\right) \delta$ : 2.14 (t, 3H, $\mathrm{CH}_{3}$ ), 3.28 (q, $\left.2 \mathrm{H}, \mathrm{CH}_{2}\right), 6.84-7.25$ $(\mathrm{m}, 6 \mathrm{H}, \mathrm{ArH}), 7.54-7.87(\mathrm{~m}, 5 \mathrm{H}, \mathrm{ArH}), 10.31$ (br, $2 \mathrm{H}, \mathrm{NH}_{2}$ exchangeable with $\mathrm{D}_{2} \mathrm{O}$ ) ppm; $\mathrm{MS} \mathrm{m} / \mathrm{z}$ (\%): $436 \quad\left(\mathrm{M}^{+}, 42\right)$ corresponding to the molecular formula $\mathrm{C}_{23} \mathrm{H}_{18} \mathrm{~N}_{3} \mathrm{SO}_{2} \mathrm{CL}$ and at 235 (100, base peak).

\section{3,5-Dioxo-4H-pyrimidino [3,2-b]naphthalino [1,2-d] thiazolo, compound 6 (TPYDb)}

Yield $64 \%$; mp $297{ }^{\circ} \mathrm{C}$; IR $\left(\mathrm{KBr}, \mathrm{cm}^{-1}\right): 1690(\mathrm{C}=\mathrm{O}$ amid); $1715\left(\mathrm{C}=\mathrm{O}\right.$ amid), ${ }^{1} \mathrm{H}-\mathrm{NMR}\left(\mathrm{DMSO}-\mathrm{d}_{6}\right) \delta$ : 7.14-7.52(m,6H,ArH)ppm; MS $\mathrm{m} / \mathrm{z}(\%)$ : $268\left(\mathrm{M}^{+}, 31\right)$ corresponding to the molecular formula $\mathrm{C}_{14} \mathrm{H}_{8} \mathrm{~N}_{2} \mathrm{SO}_{2}$ and at $172(100$, base peak).

\section{Pharmacological screening}

As shown in (Table 1), The results of metacestodes growth after in vitro cultures of $E$. multilocularis metacestodes treatment with different concentrations indicate that parasite tissue developed in all animals infected with metacestodes from cultures treated with 1,2 and $5 \mu \mathrm{M}$ of all compounds, except only TPYDa compound achieved best result at 2 and $5 \mu \mathrm{M}$ concentrations. In contrast, animals infected with metacestodes from cultures treated with $10 \mu \mathrm{M}$ of the compounds, the parasite growth was absent. SEM/TEM histology studies correlate with this observation (data not shown).

Table 1: Growth of E. multilocularis metacestode following in vitro treatment with synthetic compounds $(2-6)$ 


\begin{tabular}{|c|c|c|c|c|c|c|}
\hline \multirow{2}{*}{$\begin{array}{l}\text { TPYD } \\
\text { concentration }\end{array}$} & \multicolumn{6}{|c|}{ Growth of metacestodes } \\
\hline & DMSO* & Compound 2 & Com & ompound 4 & $\begin{array}{l}\text { Compound } 5 \\
\text { (TPYDa) }\end{array}$ & $\begin{array}{l}\text { Compound } 6 \\
\text { (TPYDb) }\end{array}$ \\
\hline $1 \mu \mathrm{M}$ & + & + & + & + & + & + \\
\hline $2 \mu \mathrm{M}$ & + & + & + & + & $+/-$ & + \\
\hline $5 \mu \mathrm{M}$ & + & + & + & + & - & + \\
\hline $10 \mu \mathrm{M}$ & + & - & - & - & - & - \\
\hline
\end{tabular}

${ }^{*}$ Control group was inoculated E. multilocularis metacestodes-treated with the solvent, DMSO, alone.

Table 2: Recovery of parasite weights (value in $\mathrm{g}$ ) from mice after bioassay, following inoculation of $E$. multilocularis metacestodes-treated in vitro with ABZ, TPYDa and combination of both (ABZ/TPYDa)

\begin{tabular}{lllll}
\hline $\begin{array}{l}\text { Mouse } \\
\text { No. }\end{array}$ & $\begin{array}{l}\text { DMSO } \\
\mathbf{3 0} \boldsymbol{\mu M}\end{array}$ & $\begin{array}{l}\text { ABZ } \\
\mathbf{3 0} \boldsymbol{\mu M}\end{array}$ & $\begin{array}{l}\text { TPYDa } \\
\mathbf{1 0} \boldsymbol{\mu M}\end{array}$ & $\begin{array}{l}\text { ABZI TPYDa } \\
\mathbf{3 0} \boldsymbol{\mu M} / \mathbf{1 0} \boldsymbol{\mu M}\end{array}$ \\
\hline 1 & $1.8 \pm 0.008$ & 0 & $0.2 \pm 0.008$ & 0 \\
2 & $2.6 \pm 0.09$ & 0 & $3.0 \pm 0.9$ & 0 \\
3 & $1.0 \pm 0.002$ & $2.2 \pm 0.08$ & $1.5 \pm 0.006$ & $0.8 \pm 0.007$ \\
4 & $2.0 \pm 0.09$ & $1.8 \pm 0.009$ & 0 & $0.3 \pm 0.009$ \\
5 & $1.9 \pm 0.008$ & $3.0 \pm 0.2$ & $2.0 \pm 0.06$ & $0.05 \pm 0.006$ \\
6 & $3.4 \pm 0.5$ & $0.6 \pm 0.001$ & $0.4 \pm 0.009$ & $0.9 \pm 0.008$ \\
7 & $2.2 \pm 0.07$ & $2.4 \pm 0.09$ & $2.3 \pm .06$ & $0.005 \pm 0.0001$ \\
8 & $3.2 \pm 0.2$ & $1.6 \pm 0.008$ & $1.6 \pm 0.009$ & $0.5 \pm 0.009$ \\
\hline${ }^{*}$ Control group was inoculated E. multilocularis metacestodes-treated with the solvent, DMSO, alone
\end{tabular}

\section{Inhibition of 14-3-3 mRNA expression}

It was earlier demonstrated that in $E$. multilocularis metacestodes 14-3-3 gene expression relative to actin, as an indicator for parasite viability. $\beta$-actin-expression was used as reference to normalize the samples. The effect on the relative 14-3-3 expression was dose dependent. TPYDa compound at $2 \mu \mathrm{M}$ concentration , 14-3-3 expression levels were reduced by one third, while 5 and $10 \mu \mathrm{M}$ concentrations reduced the levels of 14-3-3 transcripts down to approximately $66-88 \%$ of control levels (Fig.1)

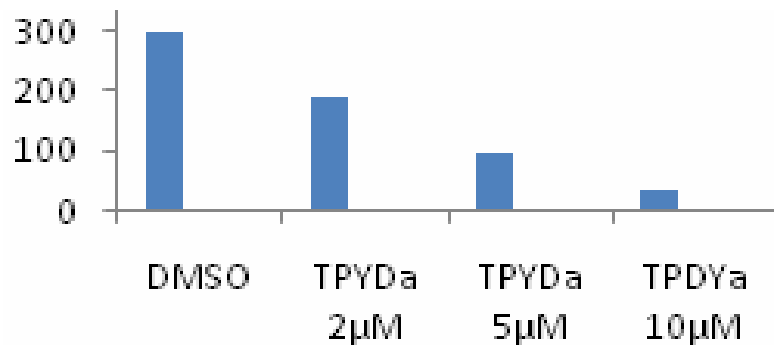

Figure 1: TPYDa treatment of E. multilocularis metacestodes 14-3-3 mRNA expression. Metacestodes were treated with $2 \mu \mathrm{M}, 5 \mu \mathrm{M}$ and 10 $\mu \mathrm{M}$ for 7 days, and transcription of the 14-3-3 gene was quantified in relation to actin by real-time PCR. Values in the $y$-axis indicate the ratio between 14-3-3 to actin transcripts.

\section{Growth of metacestodes in mice}

Incubation of metacestodes vesicles suspension with DMSO for 14 days, followed by infection of 8 mice and recovery of parasite material after 15 weeks resulted in a pronounced growth of $E$. multilocularis metacestodes, yielding parasite masses $\geq 1 \mathrm{~g}$ for all mice (range, $1.0-3.4 \mathrm{~g}$ ). TPYDa treatment alone showed fair improvement $(\sim 60 \%)$ in relation to $A B Z(\sim 63 \%)$. However, combined treatment (TPYDa/ABZ) resulted in consistently lower parasite weights ( $86 \%)$ relative to the control group and in all mice, the parasite weight was considerably $<1 \mathrm{~g}$ (Table 2 ). However, a complete parasitocidal effect was not achieved with any of these treatments. The safety of TPYD compounds and ABZ- treated E. multilocularis metacestodes suspensions on mice hepatic injury and hepatocytes damage was assessed by measuring serum levels of ALT and AST. No significant difference in serum levels of ALT and AST was noticed in all mice before sacrifice compared to the control (Table 3).

Table 3: Effect of synthesized compounds treatment on mice hepatocyte markers ALT and AST

\begin{tabular}{lcc}
\hline \multicolumn{1}{c}{ Treatment } & ALT(U/L) & AST(U/L) \\
\hline $10 \mu \mathrm{M}$ TPYDa & $37.2 \pm 0.3$ & $33.2 \pm 0.3$ \\
$30 \mu \mathrm{M} \mathrm{ABZ}$ & $34.8 \pm 0.5$ & $31.9 \pm 0.4$ \\
$10 \mu \mathrm{M}$ TPYDa/30 $\mu \mathrm{M} \mathrm{ABZ}$ & $35.9 \pm 0.4$ & $34.3 \pm 0.2$ \\
\hline${ }^{*}$ No significant difference between all mice relative to control \\
$(p<0.05)$
\end{tabular}

\section{DISCUSSION}


In previous work we have reported the synthesis of thiazolo derivatives used $\alpha$-amino naphthol 1. The reaction of compound 1 with KSCN afforded 2 -amino thiazolo derivatives 2 . The reaction of compound 2 with sodium nitrite and hydrochloric acid afforded the corresponding thiazolo derivatives 3 , which converted to 2-hydrazino thiazolo derivatives 4 (Scheme 1). Reaction of hydrazino thiazolo derivatives 4 with benzylidine derivatives afforded pyrimidino thiazolo derivative 5. Also, hydrazino thiazolo derivatives 4 was reacted with diethyl malonate to afford pyrimidino thiazolo derivative 6 (Scheme 2). All the synthesized compounds were confirmed by spectral data (IR, ${ }^{1} \mathrm{H}-\mathrm{NMR}$ and mass spectra). Structure activity relationships based on the obtained results indicated that, substitution of 3Amino-4-ethoxy carbonyl pyrimidino thiazolo derivatives had anti proliferative growth effect of E. multilocularis metacestodes.

We initially investigated whether the new synthetic TPYD treatment would affect 14-3-3 mRNA expression in $E$. multilocularis metacestodes. In our work, 14-3-3 transcript levels were reduced by one third upon treatment with $2 \mu \mathrm{M}$ concentration of the compound and more drastically reduced upon treatment with 5 $\mu \mathrm{M}$ and $10 \mu \mathrm{M}$ concentrations. This dose dependent reduction in 14-3-3 expression levels especially at higher concentrations, was accompanied by completely distorted germinal layer-associated parasite tissue with major morphological and ultra structural changes seen by SEM/TEM (data not shown). There is an association between the uncontrolled proliferation and the over-expression of a family of proteins named 14-3-3 proteins in echinococcus metacestodes. This suggests that treatments interfering with 14-3-3-proteinexpression and/or function could interfere with the growth of the metacestodes [4]. Our results showed the inhibition effect of TPYD compounds on E. multilocularis metacestodes tumor-like proliferation was in consistence with previous results showed that hetero-cyclic compounds were potent anti-tumor agents [14,15].

Compound TPYDa showed potent anthelmintic activity and emerged as the most active agent of the synthetic compounds that might be due to the presence of electron-donating moiety which increased the pharmacological activity and it was moderately more potent as the traditional anthelmintic drug ABZ. When TPYDa combined with $A B Z$, increased the cure rate of $E$. multilocularis metacestodes treatment. In the future, this combination treatment could minimize the high recurrence rate of echinococcosis in human clinical application.

\section{CONCLUSION}

The study shows synthetic heterocyclic organic compounds, a new series of substituted amino thiazole, hydrazinothiazole and thiazolo pyrimidine derivatives (2-6), are promising candidates for the development of new anthelmintic agents with rapid regeneration and hepatic physiological and pathological functional reformation of damaged compressed liver tissue caused by the tumor-like infiltrative growth of the parasite hepatic lesions.

\section{ACKNOWLEDGMENT}

This work was fully supported by Scientic Research Deanship, Taibah University, Ministry of Higher Education, Saudi Arabia, Grant \# 311/432. The authors are grateful to Taibah University President and Dean of Scientific Research for their support.

\section{REFERENCES}

1 Spicher M, Naguleswaran A, Ortega-Mora LM, Muller J, Gottstein $B$, Hemphill $A$. In vitro and in vivo effects of 2-methoxyestradiol, either alone or combined with albendazole, against Echinoccocus metacestodes. Exp Parasitol 2008; 119: 467-474.

2 Hemphill $A$ and Walker $M$. Drugs against Echinococcosis. Drug Design Reviews 2004; 1: 325-332.

3 Reuter S, Buck A, Manfras B, kratzer W, Seitz HM, Darge K, Reske SN, Kern P. Structured treatment interruption in patients with Alveolar Echinococcosis. Hepatology 2004; 39: 509-515.

4 Siles-Lucas M, Gottstein B. The 14-3-3 proteins a key molecule in parasites as in other organisms. Trends in Parasitology 2003; 19: 575-581.

5 Klinkert $M Q$ and Heussler V. The use of anti-cancer drugs in antiparasitic chemotherapy. Mini-reviews in Medicinal Chemistry 2006; 6: 131-143.

6 Hemphill A, Spicher M, Stadelmann B, Muller J, Naguleswaran A, Gottstein B, Walker $M$. Innovative chemotherapeutical treatment option for Alveolar and Cystic Echinococcosis. Parasitolgy 2007; 134 (12): 1657-1670.

7 Keshamouni VG, Michailidis G, Grasso CS, Anthwal S, Strahler JR, Walker A, Arenberg DA, Reddy RC, Akulapalli S, Thannickal VJ, Standiford TJ, Andrews PC, Omenn GS. Differential protein expression profiling by ITRAQ-2DLC-MS/MS of lung cancer cells undergoing epithelialmesenchymal transition reveals a migratory/invasive phenotype. Journal of Proteome Research 2006; 5: 1143-1154.

8 Naif OA, Saleh AB, Ahmed AF, Moutasem SA, Amr AE. Anti-parkinsonism, hypoglycemic and antimicrobial activities of new poly fused ring heterocyclic candidates, International Journal Biological Macromolecules 2013; 57: 165 -173.

9 Ouf NH, Amr AE. Synthesis and anti-inflammatory activities of some pyrimidines and theinopyrimidines using 1-(2-Benzo[d][1,3]dioxol5-ylOvinyl)-4-mercapto-6-methylpyrimidine-5-

Trop J Pharm Res, December 2013;12 (6): 994 
yl)ethan-2-one as a starting material. Monatshefte für Chemie 2008; 139 (5): 579- 585.

10 Rashad AE, Shamroukh AH, Abdel-Megeid RA, Sayed $H H$, Abdel-Wahed NM. Studies on the Reactivity of (9-Methyl-5,6-dihydronaphtho[1',2':4,5]thieno[2,3-d]pyrimidin-11-yl)hydrazine Towards Some Reagents for Biological Evaluation, Scientia Pharmaceutica 2010; 78: 1-12.

11 Rashad AE, Shamroukh AH, Abdel-Megeid RE, Mostafa A, El-Shesheny R, Kandeil A, Mohamed A., Banert K. Synthesis and screening of some novel fused thiophene and thienopyrimidine derivatives for anti-avian influenza virus (H5N1) activity, European Journal of Medicinal Chemistry 2010; 45 (11): 5251-5257.

12 Rashad AE, Ali M. Synthesis and Antiviral Screening of Some Thieno[2,3- d ]Pyrimidine Nucleosides, Nucleosides Nucleotides and Nucleic Acids 2006; 25 (1): $17-28$

13 Ramakrishna VS, Kothmirkar P, Arepalli S, Reddy G. Convenient and Efficient Synthesis of Some Novel Fused Thieno Pyrimidines Using Gewald's Reaction. Synthetic Communications 2011; 41 (19): 2835-2851.

14 Witheringron J, Bordas V, Garland SL, Hickey DM, Life RJ, Liddle J, Saunders M, Smith DG, Ward RW. 5Aryl-pyrazolo[3,4-b]pyridins potent inhibitors of glycogen synthase kinase-3-(GSK-3). Bio-organic Medicine Chemistry letter 2003; 13: 1577-1580.
15 Lin R, Connolly PJ, Lu Y, Chin G, Li S, Huang S, Greenberg $L M$. Synthesis and evaluation of pyrazolo[3,4b]pyridine CDK1 inhibitors as antitumor. Bio-organic Medicine Chemistry letter 2007; 17: 4292-4302.

16 Hemphill A, Stettler M, Walker M, Siles-Lucas M, Fink $R$, Gottstein B. Culture of Echinococcus multilocularis metacestodes: as alternative to animal use. Trends in Parasitology 2002; 18: 445451.

17 Hemphill A, Croft SL. Electron microscopy in parasitology. In: Rogan $M(E d)$, Analytical Parasitology. Springer - Verlag, Heidlberg, Germany, 1997; pp 227-268.

18 Matsumoto J, Muller N, Hemphill A, Oku Y, Kamiya M, Gottstein B. 14-3-3- and II/3-10- gene expression as molecular markers to address viability and growth activity of E. multilocularis metacestodes. Parasitology 2006; 132: 83-94.

19 Stettler M, Rossingol JF, Fink R, Walker M, Gottstein B, Merli $M$, Theurillat $R$, Thormann $W$, Dricot $E$, Segers R, Hemphill A. Secondary and primary murine alveolar Echinococcosis combined albendazole/nitazoxide chemotherapy exhibits profound anti-parasitic activity. International Journal for parasitology 2004; 34: 615-624. 